\title{
18. Private sector development
}

\section{Nicholas Lardy}

There is a widespread belief that the unprecedented pace and duration of China's economic growth is because China has developed a unique model of economic growth. This model is variously referred to as 'state capitalism', 'authoritarian capitalism', 'corporate Leninism' or 'regulatory capitalism' (McGregor 2012: 31). Those who believe that China has developed a unique economic model do not dispute the view that markets and private enterprise have come to play a substantially more important role since economic reform began in China in 1978 . They acknowledge that reforms in the countryside in the first half of the 1980s effectively converted collective farming into private agriculture. They recognise that the state has largely abandoned its once pervasive control of prices in favour of market-determined prices for all but a few goods and services. And they concede that large parts of China's manufacturing industry, particularly consumer goods, are produced in private factories and distributed through wholesale and retail networks that are mostly privately owned and operated. And, of course, observation confirms that privately owned and operated hotels, restaurants and some other types of service firms have become pervasive in urban China.

But the proponents of the view that China has developed a unique economic model maintain that the state, through various mechanisms, retains control of what is sometimes referred to as the commanding heights of the economy. These mechanisms include continued dominant state ownership of critical industries, the widespread use of industrial policies developed by various state agencies, the proliferation of government funds designed to promote various government objectives and the continued state domination of the banking system, which also is used to promote various government policies. Some of these tools of government control are longstanding; others have emerged only in the past decade. These mechanisms have been noted in much academic writing (for example, Naughton 2016: 55-77) and the US Government pointed to these and other mechanisms as part of the basis for its refusal in 2017 to grant China market economy status (US Department of Commerce 2018).

While there have been some elements of economic policy in the past decade that reflect a resurgence of the state, this chapter argues that, in a 40-year perspective, the private sector has had a dominant role in China's economic transformation. The important caveat is that while the state sector has been drastically reduced in terms of its contribution to output and employment, its declining productivity since 
the Global Financial Crisis (GFC) combined with a growing claim on bank credit starting in 2013 mean that state-owned enterprises (SOEs) are a drag on China's economic growth.

\section{The displacement of SOEs}

The rise of private business in China since 1978 is largely the result of what might be called the displacement of SOEs. Unlike some other formerly centrally planned economies, in China, privatisation of SOEs has been only a minor contributor to the rise of private business. Rather, private firms have grown much more rapidly than SOEs. Displacement of SOEs in terms of output, investment and employment has been facilitated by three factors. First, the government and the Communist Party of China (CPC) very gradually opened the space in which private firms could operate. Second, private firms on average have been far more productive than SOEs, generating a high level of profits relative to their assets. Private entrepreneurs have reinvested these profits, leading to a pace of growth that SOEs ultimately could not match. Third, over time, private firms were able to borrow increasing amounts from banks and also were able to raise funds on the Shanghai and Shenzhen stock markets.

In the first decade or so of reform, government policy opened the economy to private economic activity only very slowly. As early as 1978, the National People's Congress adopted a constitutional amendment allowing 'individual labourers' to operate, but restricted the scope of these businesses by forbidding employment of more than seven nonfamily members. And, in 1982, the Chinese constitution was revised to include, for the first time, a provision protecting private property rights (Garnaut et al. 2005: 198). But not until 1988 did the government promulgate the Provisional Regulations on Private Enterprises, which for the first time provided a legal framework for private firms with eight or more nonfamily members.

In the mid-1990s, the implementation of the Company Law further boosted China's private sector. First, this law allowed private firms to organise as limited liability companies, meaning the personal wealth of an entrepreneur could be separated from the assets of the entrepreneur's business. Second, it facilitated the reregistration of more than a million collective firms as private companies-a process sometimes referred to as 'taking off the red hat'. In 2005 and again in 2010, the government lifted restrictions on the entry of private businesses into an increasing range of industries, such as civil aviation, which previously were reserved exclusively for SOEs. The government in 2008 began to provide special tax incentives for private companies - notably a lower corporate income tax rate and exemptions from the value-added and business taxes for firms with annual taxable income below certain thresholds (Lardy 2014: 89-93). 
The attitude of the government and the CPC towards private firms also further evolved in important ways that supported the rise of the private sector. Initially, official documents did not even refer to the private sector but acknowledged the nonstate sector (which included collective firms) as an important component of the state-dominated economy. In 1999, in a constitutional amendment, the nonstate sector was upgraded to 'an essential component of a mixed economy' (Lardy 2014: 91). On the eightieth anniversary of the CPC in 2001, then general secretary Jiang Zemin invited private entrepreneurs to join the party, leading to a substantial change in the composition of party membership, away from workers and peasants towards wealthy private businesspeople (McGregor 2010: 31).

A second factor facilitating displacement of SOEs is that private firms have been far more efficient than SOEs, particularly as measured by return on assets. The dismal economic performance of SOEs in the 1980s and 1990s was made painfully clear by an accumulation of nonperforming loans (NPLs) in the banking system that was so large that, by 1997, China's largest state-owned banks, which lent predominantly to SOEs, were insolvent (Lardy 1998: 5). Premier Zhu Rongji led a two-pronged initiative to avoid a banking and financial crisis. The first prong was a substantial restructuring of the state sector. This led to the closure of thousands of mostly money-losing SOEs and the loss of tens of millions of jobs. The second component of Zhu's reforms was a massive write-off of NPLs by state-owned banks and their recapitalisation by the government. The most comprehensive estimate of the costs of restructuring China's banks from the late 1990s through to late 2005 is RMB4 trillion (Ma 2007: 31).

In the industrial sector, where we can measure the results of Zhu's reforms most accurately, the return on assets of SOEs rose rapidly from the late 1990s through to 2007, substantially reducing, though not eliminating, the underperformance of SOEs relative to private firms. However, since the GFC, the productivity gap between state and private industrial firms has widened significantly. As shown in Figure 18.1 , by 2016 , the returns of industrial SOEs had fallen by almost threefifths from their high point in 2007, to only 3 per cent, while private industrial firms earned returns of 10.6 per cent-more than 1 percentage point higher than in 2007. As a result, the return on assets of registered private industrial firms in 2016 was three-and-a-half times that of SOEs-proportionately the largest gap in almost 20 years. 


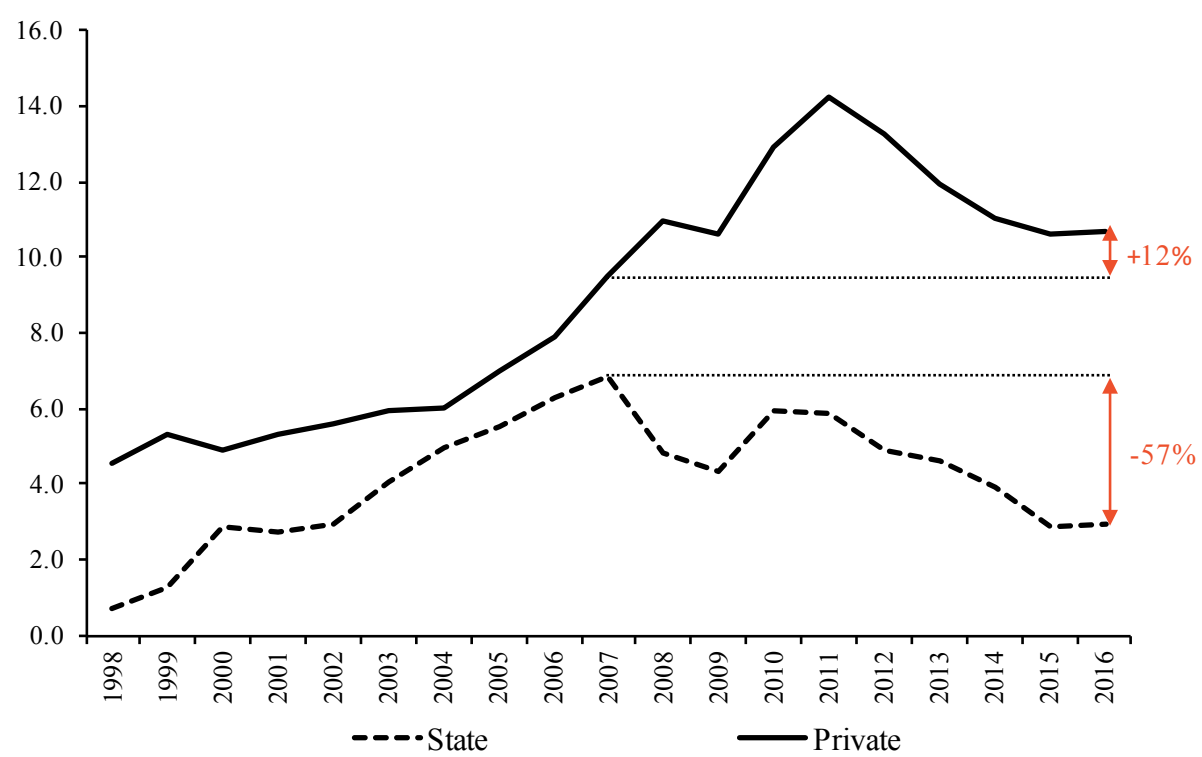

Figure 18.1 Return on assets of state and private industrial enterprises, 1998-2016 (per cent)

Source: NBS (2017: 424-5, 430-1); National Bureau of Statistics of China website (data.stats.gov.cn; accessed 5 September 2017).

The third factor facilitating the growth of private businesses was the increasing access of these firms to bank credit and funds raised through initial public offerings (IPOs) on the domestic stock markets and the sale of bonds. This process was very gradual; China's predominantly state-owned banking system initially directed almost all credit to SOEs. Flows of credit to private firms in the initial years of the reform process were miniscule, which is hardly surprising given official antipathy at the time towards private nonagricultural businesses and the state banks' lack of the credit skills needed to lend to small private companies. This began to change when China's central bank in the mid-1980s formally authorised the creation of urban credit cooperatives. This network grew rapidly and, by 1995, these cooperatives had become the principal source of formal credit for small private companies (Lardy 2014: 103). Eventually the large state banks, recognising that highly profitable private firms were on average more creditworthy than money-losing SOEs, directed a larger and larger share of their corporate lending to private firms. The story was similar in the equity market, where initially almost all IPOs were by SOEs. Over time, the mix changed. By 2017, 377 private firms went public, while only 31 SOEs did the same. ${ }^{1}$

1 In 2017, however, SOEs raised more money via the domestic stock markets because they dominated secondary offerings, which were much larger in terms of funds raised than IPOs (data from Wind). 
These three factors - the opening of the economic space available to private firms, the superior financial performance of private firms and the increased access of these firms to funds from banks and the domestic stock markets-facilitated the process of displacement of state by private firms. This displacement in terms of output is easiest to analyse in China's industrial sector, which on the eve of reform accounted for more than two-fifths of gross domestic product (GDP) (NBS 2016a: 21-2). As shown in Figure 18.2, in 1978, SOEs accounted for almost four-fifths of industrial output (Lardy 2014: 75). ${ }^{2}$ By 2015, this share had shrunk to one-fifth (NBS 2016b: 419, 427-8). ${ }^{3}$ But, since China's industrial output in constant prices by 2015 was 47 times the level of 1978, the output of SOEs in 2015 was 12 times the level of 1978. Clearly, while industrial SOEs are shrinking rapidly in relative terms, they continue to expand in absolute terms.

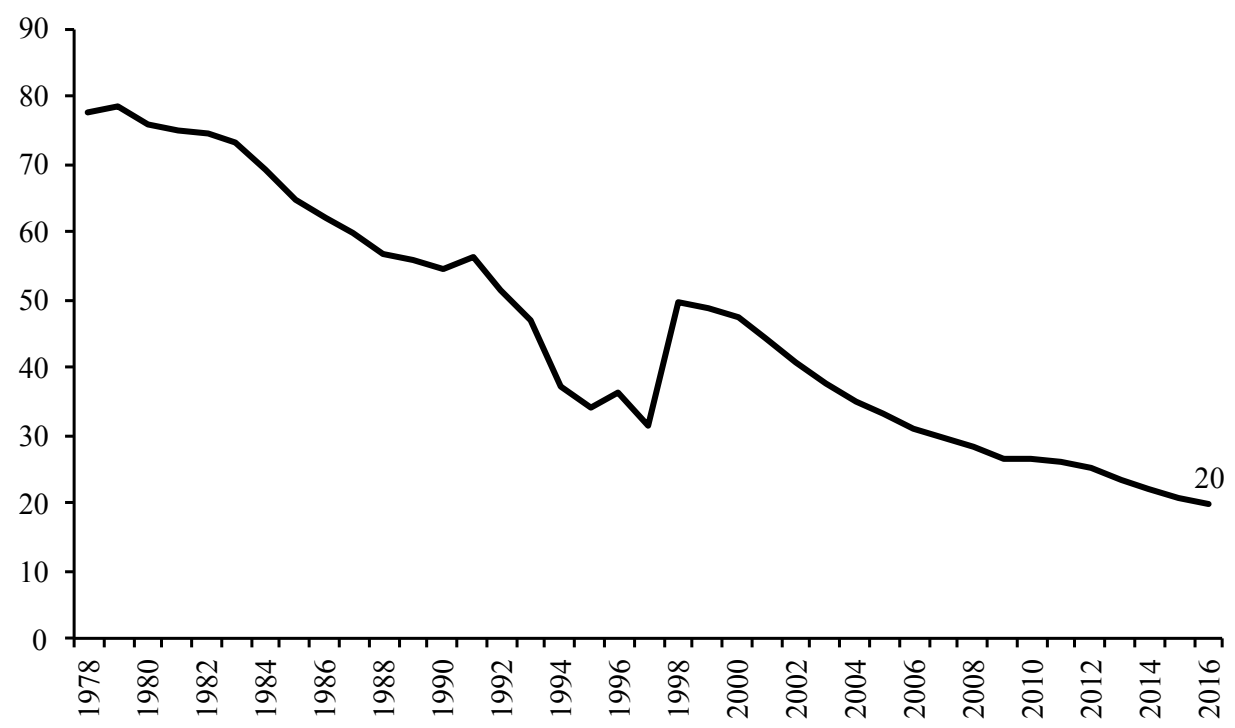

Figure 18.2 Gross industrial output of state enterprises, 1978-2016 (percentage of total gross industrial output)

Notes: Data include only above-scale firms, with sales greater than RMB5 million (1998-2011) and firms with sales greater than RMB20 million (beginning in 2011). This data series was discontinued after 2011 , so in this figure data for $2012-16$ are the state share of industrial sales value-a proxy for gross industrial output.

Source: Lardy (2014: 75); National Bureau of Statistics of China website (data.stats.gov.cn; accessed 12 June 2018).

2 The state share in 1978 is based on gross value of industrial output. Throughout this chapter, data on the share of state output and investment are inclusive of output and investment of traditional SOEs and traditional SOEs that have been transformed into limited liability and shareholding firms in which the state is in control because it is the sole, majority or dominant owner. For details, see Lardy (2016: 38).

3 Since gross value data disaggregated by ownership are no longer published, the state share in 2015 is based on revenue from principal business. 
A major factor leading to the pattern of relative displacement of SOEs in terms of output was the diminished role of these companies in investment in industry. In the early years of reform, the majority of industrial investment was undertaken by SOEs and financed through the state budget. But budgetary financing of investment was gradually phased out by the mid-1990s. So, SOEs became increasingly dependent on retained earnings to finance investment. Because of the weakening financial performance of industrial SOEs by 2006, their share of all industrial investment had fallen to two-fifths and, by 2015, fell further to well under one-fifth (NBS 2007: 206-7; 2016b: 318-19).

While this transformation since 1978 has been dramatic, the pace of displacement of industrial SOEs in terms of both output and investment has an important limit. The reason is that industry, in Chinese statistical practice, consists of manufacturing, mining and utilities and these domains are not equally open to private firms. Most manufacturing is open to private firms and, by 2015, the SOEs' share of output had been reduced to 16 per cent. Mining and especially utilities, which accounted for 6 and 5 per cent of industrial output in 2015, respectively, are less open to private firms, so SOEs still accounted for 48 and 88 per cent of output in these two domains, respectively (NBS 2016b: 420-3, 426-9).

In contrast, in the service sector, the role of SOEs remains much more important than in industry. While comprehensive data on service sector output disaggregated by ownership are not published, the continued importance of SOEs is confirmed in investment data.

The last indicator of the displacement of SOEs is employment. In urban China in 1978, there were no private firms and individual businesses (sometimes referred to as self-employed) had only 150,000 workers-less than two-tenths of 1 per cent of urban employment. SOEs and government agencies employed 75 million workers and collective units-largely controlled and usually at least partially owned by local governments-employed another 20 million people. Employment in SOEs - that is, excluding those employed by government agencies-declined from about 59.8 million or 27 per cent of the urban workforce in 1999 to 46.9 million or 11 per cent of the workforce in 2016 (Lardy 2014: 139; NBS and Ministry of Human Resources and Social Security 2018: 262).

\section{Mechanisms of state control}

If private firms have displaced SOEs as measured by output, investment and employment, what are the potential mechanisms through which the state still exercises control and how important are these mechanisms? 
One potentially important mechanism is continued dominant state ownership of critical industries. As already noted, the average share of state-controlled output across all industries has declined, but this may mask substantial variation, with the state continuing to dominate the most critical industries. Indeed, a 2006 policy document of the State-owned Assets Supervision and Administration Commission (SASAC) called for 'maintaining state ownership as the main element of the economy, concentrating state assets in important sectors' and what it called 'critical realms and strengthening the controlling power and leading role of the state economy' (Lardy 2014: 54). The document also specifically identified seven so-called strategic industries in which the state must maintain 'absolute controlling power' and nine so-called pillar industries in which the state must maintain 'relatively strong control' (SASAC 2006). The strategic industries include defence, electricity production and distribution, petroleum, telecommunications, coal, civil aviation and shipping.

It is not clear, however, whether state control in most of these strategic industries differentiates China from many other market-oriented economies. The defence industry is a special case in all major global powers and is not considered further in this chapter. State ownership or a high degree of regulation of electricity, petroleum, telecommunications and civil aviation is commonly observed in many economies. Electric power generation and distribution are a natural monopoly that means direct government ownership or heavy regulation is universal. Pemex in Mexico and Petrobras in Brazil are good examples of state monopolies in petroleum in market economies. Majority government ownership of Singapore Airlines and Thai Airways International does not lead us to believe that Singapore and Thailand are statecontrolled economies.

Coal is a more interesting strategic industry because it is not a natural monopoly, and globally in recent decades there are few, if any, coal industries that are state owned or state controlled. But it does not appear that the Chinese Government has successfully exercised absolute controlling power of this industry. In 2005, just prior to the policy announcement on strategic industries, state coalmines produced 70 per cent of the industry's output. A decade later, the state share had fallen to less than 60 per cent (NBS 2006: 510-13, 520-3; 2016b: 420-3, 426-9).

A similar pattern prevails for steel-one of the nine pillar industries in which SASAC declared it would maintain relatively strong controlling power. In 2005, state steel companies were responsible for 49 per cent of the industry's output; by 2015, their share had declined to 28 per cent (NBS 2006: 510-13, 520-3; 2016b: 420-3, 426-9). The state may aspire to retain absolute power in the coal industry and relatively strong controlling power in the steel industry, but the evidence shows these industries are not an exception to the broad pattern in which SOEs are steadily losing market share to more efficient private firms. ${ }^{4}$

4 An exception is the tobacco industry, where the state, through its aptly named State Tobacco Monopoly Administration, continues to control 99.3 per cent of output in the industry. 
Industrial policy is a second mechanism through which the Chinese Government seeks to exert continued economic control. The success of industrial policies everywhere is difficult to judge. What is the counterfactual—that is, what would have happened in the absence of such policies? Almost all the strategic and pillar industries identified in the government's 2006 industrial policy are in the manufacturing sector. It is not obvious whether the government has been able to maintain state ownership and concentrate state assets in the critical realms it has identified. As already noted, the share of manufacturing output accounted for by SOEs had fallen to just 16 per cent by 2015 . The share of investment by SOEs in manufacturing fell from 22 per cent in 2006 to less than 8 per cent by 2015. Private firms account for more than three-quarters of investment in the manufacturing sector. ${ }^{5}$ Even in narrowly defined strategic and pillar industries within manufacturing, such as coal and steel, the share of output produced in SOEs has fallen significantly since state ownership of these industries was first prioritised.

The most sustained industrial policy China has pursued is associated with SASAC. SASAC was established formally in 2003 when, at the central government level, it assumed oversight of about 200 of China's largest firms, including the three state oil companies, the three state telecommunications companies, most of the large stateowned power generating companies, the two state power distribution companies, the major state airlines, and so forth. All of these firms were large group companies or holding companies, each with numerous subsidiaries. Counting subsidiaries three levels down from the parent, these companies in 2010 controlled 23,738 firmsabout one-fifth of all state nonfinancial companies. ${ }^{6}$ Including 52,371 subsidiaries of group companies controlled by SASAC entities at the provincial level, SASAC controls three-fifths of all state nonfinancial companies. SASAC was charged with transforming these companies into so-called national champions.

While the creation of SASAC is certainly consistent with the view that the state has sought a more direct role in promoting economic development, it almost certainly should be judged a failure. Operationally, SASAC has focused on mergers of its firms within the same industry and capturing more funds for investment. As a result, central SASAC orchestrated dozens of mergers, in the process reducing the initial roughly 200 firms to less than 100 by mid-2017. Most of these mergers were of firms within the same industry. For example, SASAC merged China Ocean Shipping Group with China Shipping Group and merged the two rail car producers, CNR Corporation and CSR Corporation.

5 Private here includes registered private companies and limited liability and shareholding limited firms in which the sole, majority or dominant owner is private.

6 State ownership of most financial firms is vested in Central Huijin, a unit of the Chinese Investment Corporation-sometimes regarded as China's sovereign wealth fund. 
SASAC firms were also showered with bank loans and were able to raise additional funds through initial and secondary public offerings on the Shanghai stock exchange and bond issuance. As a result, the assets controlled by SASAC firms soared from RMB10.6 trillion in 2005 to RMB54.54 trillion at the end of 2017. The increase of about RMB45 trillion is fully four times the after-tax profits these firms generated between 2005 and $2017 .{ }^{7}$ Yet the return on assets of the universe of SASAC firms fell from 6 per cent in 2005 to only 2.4 per cent in 2015 and 2016, before recovering very slightly to 2.6 per cent in 2017 .

Another potential mechanism of state control is government-run financing agencies that emerged starting in 2010. The earliest were technology funds-mostly established at the provincial level—to support long-term science and technology policy. More recently, the Chinese Government has established investment funds and state capital investment and operations funds that invest in priority growth areas. By the end of 2015, there were 780 investment funds, with RMB2.18 trillion in capital (Kennedy and Johnson 2016: 27). Since then, SASAC has established two additional large funds, the State-Owned Enterprise Structural Adjustment Fund and the China Reform Fund. By the end of 2016, government-run funds managed about RMB3.6 trillion (Mano and Stokoe 2017).

It is too soon to evaluate the success of these funds in promoting state economic policy. Several caveats are in order. First, although the reported cumulative magnitude of the funds seems large, it is not clear how quickly these funds are being invested. Firms raised only RMB1.1 trillion on the Shanghai and Shenzhen stock markets in 2017, so if these government funds are deployed quickly they could become more important than the domestic stock markets. Second, it is not clear the extent to which these funds will become a replacement for bank lending. The state may be more successful in promoting the development of the semiconductor industry through its National Integrated Circuit Investment Fund, financed in part by banks, than through uncoordinated bank lending in support of the industry.

The third mechanism of continuing state control is the state-dominated banking system. China remains a very bank-dominated financial system and almost the entire banking system is state controlled. Yes, China's largest state-owned banks have been listed on public markets, but typically only a minority of the shares of each bank have been sold to investors, meaning the banks remain state controlled. For China's largest state banks, this control is exercised by the central government and the Organisation Department of the CPC nominates the top leadership of each bank. For smaller institutions, such as joint stock banks and city commercial banks, some of which are also publicly listed, the controlling shareholder is a provincial or municipal government and presumably top managers of each bank are vetted by the

7 After-tax profits are estimated by applying the 25 per cent corporate tax rate to the reported pre-tax profits of SASAC firms. 
CPC Organisation Department at the provincial or municipal level. There are only a handful of truly private banks — all quite small — and although there are numerous foreign banks, cumulatively, they control less than 2 per cent of bank assets.

\section{Resurgence of the state?}

In the northern autumn of 2013, a year into the leadership regime of President $\mathrm{Xi}$ Jinping and Premier Li Keqiang, the CPC endorsed a far-reaching economic reform program that, among other things, called for the market to play the dominant role in the allocation of resources (CPC Central Committee 2013). Five years later, however, most observers argue that little of this ambitious reform agenda has been implemented. Instead, China has announced a series of industrial policies that promote SOEs at the expense of private and foreign firms; the flow of bank lending to private firms has declined, not only as a share of the total flow of loans to corporate firms, but also in absolute terms; and President $\mathrm{Xi}$ in his first fiveyear term focused on his signature anticorruption campaign and consolidating his political power. This culminated in the northern spring of 2018 in a revision to the Chinese constitution that drops the clause limiting the term of office of China's president to two five-year terms.

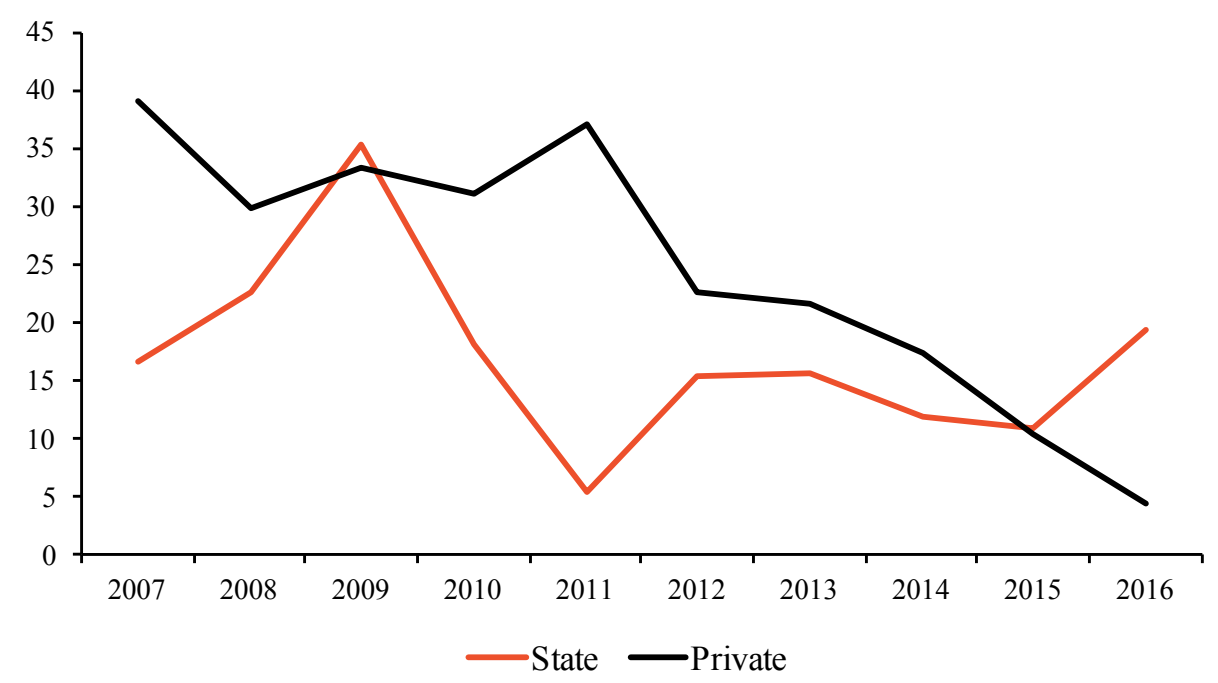

Figure 18.3 Growth of state and private investment, 2007-16 (per cent, year over year)

Source: NBS (2017: 310-11); National Bureau of Statistics of China website (data.stats.gov.cn; accessed 5 September 2017). 
The clearest empirical evidence of the resurgence of the state is in the investment realm. As reflected in Figure 18.3, from 2006 to 2011, the growth of private investment was quite strong-indeed, on average, it expanded at a pace about two and half times that of state investment. This pushed up the share of private investment from 36 per cent to 48 per cent. But from 2011, the pace of growth of private investment slowed dramatically, while the pace of state investment rose. By 2016, state investment grew at several times the pace of private investment.

The most plausible explanation of the waning of private investment is crowding out - an explanation supported by several pieces of evidence. First, the share of bank loans to nonfinancial corporations that went to private firms fell from 57 per cent in 2013 to only 19 per cent by 2015 , while the share that went to SOEs almost doubled over the same period-from 35 per cent to 69 per cent. Second, financing of private firms through microfinance companies stalled after 2015. Lending by these companies grew rapidly from 2008, when the People's Bank of China and the China Securities Regulatory Commission first issued formal guidelines on microfinance companies. The volume of such lending levelled off at just less than RMB1 trillion in 2014, but has not grown since. ${ }^{8}$

Third, between 2011 and 2015, SOEs' profits rose by only RMB30 billion, or 1 percentage point, while the investment of these firms rose by almost RMB2 trillion, or more than 20 per cent. Much of the differential between the growth of investment and the growth of profits must have come from increased borrowing from banks.

Fourth, indirect evidence suggests that SOEs have borrowed increasing amounts of funds to cover their financial losses. In 2005, 50 per cent of all SOEs were lossmaking. By 2016, the share of lossmaking SOEs had declined slightly, to 45 per cent. Thus, roughly half of China's SOEs for more than a decade have been unable to fully cover their cost of capital. Moreover, the magnitude of losses generated by lossmaking firms increased sevenfold, from RMB243 billion in 2005 to RMB1.95 trillion in 2016. As a share of GDP, these losses doubled, from 1.3 per cent in 2006 to 2.6 per cent in 2016 (MOF 2015: 374; 2016: 369).

The rapid increase in the magnitude of SOE losses appears consistent with the decline in the return on assets of SOEs in this period. When the average return on assets falls persistently, the share of firms with negative returns and the magnitude of losses both naturally increase. Since very few firms go bankrupt or are taken over through merger and acquisition activity, it appears increased borrowing from banks covers a substantial portion of these financial losses. In the industrial sector, for example, the ratio of debt to equity or leverage ratio of SOEs increased from 132 per cent in 2005 to 163 per cent in 2015. When a large share of firms are lossmaking but they borrow money to finance investment, they are unable to fully cover their cost of loans and inevitably can stay in operation only by rolling over their loans - in

8 Data on microfinance lending are from Wind. 
the process adding unpaid interest on the prior loans to the principal of the new loan. Inevitably, that means debt increases more rapidly than assets, equity falls and the ratio of debt to equity rises.

Private industrial firms also borrow to finance investment, but on average they earn returns that are three times those of SOEs and the incidence of lossmaking is only one-third that of SOEs, so, on average, they easily repay their loans. The borrowed funds are used to finance investment in plant and equipment, raising firms' assets. The subsequent repayment of the loans from profits reduces firms' liabilities. Thus equity (which equals assets minus liabilities) rises and the leverage ratio falls. The leverage ratio of private companies in 2005 was 147 per cent, but by 2015 it had fallen to 109 per cent.

Taken together, the evidence on investment and leverage suggests that, starting in 2012 and accelerating in 2016-17, SOEs have had an increasing claim on the loanable funds of the banking system. They have used these funds both to increase their share of investment and to offset the losses of the large fraction of SOEs that are lossmaking. Unfortunately, the returns on these investments continue to fall and the share of increased bank credit used to offset losses appears to be rising.

\section{SOEs drag down China's growth}

While private firms have been the dominant source of growth in output and employment over the past four decades, the resurgence of the state in the past five years has been inimical for China's growth for two reasons. First, President Xi has repeatedly called to make state firms larger and better. The former has certainly been achieved, largely due to mergers within the SASAC universe. No Chinese company was included in the Fortune Global 500 list when reform began. In 1996, two Chinese firms made the list, but by 2017 Chinese firms occupied 109 spots on the list, including three in the top 10. Virtually all of the Chinese firms on the Fortune 500 list are state controlled and many are group companies in the SASAC universe.

But the Fortune Global 500 is a ranking of companies by revenue; no consideration is given to any measure of efficiency, such as return on assets or return on equity. As Chinese SOEs have bulked up through mergers and additional investment, the number included on the Fortune Global 500 list has inevitably grown, but the efficiency of these firms has fallen. In 2015, for example, 12 of the 98 Chinese companies on the list were lossmaking. And, as previously noted, the return on assets of the large subset of state firms under the administration of central SASAC has fallen sharply since the GFC. The same is true of the broader SOE universe. The return on assets for SOEs in industry and construction fell from 5.5 per cent in 2007 to only 1.8 per cent in 2016; in services, the decline was from 4.1 per cent to 1.6 per cent (MOF 2015: 384, 388; 2017: 379, 383). 
The second reason the resurgence of the state has been inimical for China's growth is that investment in the far more efficient private sector has been increasingly crowded out. This slowdown of private relative to state investment began in 2012 and became much more acute in 2016 when the growth of state investment surpassed the pace of private investment by a wide margin.

The central conclusion of this chapter is that China's economic growth in the reform era has been driven by the private sector operating in an increasingly market-oriented environment. In recent years, however, the state banks have allocated a growing share of their loans to SOEs. This is despite evidence that the performance of SOEs has declined precipitously in absolute terms and even more relative to private firms. Thus, a secondary conclusion of the chapter is that China's growth in recent years has been below potential.

China's growth in the first three-and-a-half decades of economic reform was largely due to an expanding role of markets and private firms. Since Xi Jinping came to power in 2012, there has been a new emphasis on state enterprises, industrial policy and the role of the party in the economy. This approach endures despite evidence that SOE performance continues to decline, both in absolute terms and even more relative to private firms.

Capturing China's potential for faster growth would require substantial additional economic reforms to raise the productivity of SOEs. First, China should suspend or even reverse the policy of creating ever larger SOEs through top-down, governmentorchestrated mergers. The net effect of this program over more than a decade has been to reduce competition. These mergers have increased the market power of SOEs in many domains, inevitably reducing the incentive for innovation and cost reduction, leading to predictable declines in efficiency.

Second, the government should open up the portions of the economy where entry by private firms is still restricted-notably, in large parts of the service sector. Again, this would increase competitive pressure and perhaps lead to productivity improvements in SOEs.

Third, the government should encourage more market-driven merger and acquisition activity so that more efficient private firms could acquire the assets of state companies that remain underperforming, even in the more competitive environment envisioned above.

Fourth, Articles 4 and 41 of the Commercial Bank Law, promulgated more than two decades ago, should be strictly enforced (NPC Standing Committee 1995: 335-9). Article 4 states that commercial banks must 'operate on the principles of efficiency, safety, and liquidity; exercise independent operation; bear their own risks; assume exclusive responsibility for profits and losses'. Article 41 states that 'no unit or individual may compel a commercial bank to extend loans or provide 
guarantees'. Enforcement of these provisions would preclude local politicians from leaning on banks to extend loans to underperforming and money-losing companies that otherwise might have to suspend their operations. It would incentivise banks to direct more lending to more creditworthy, predominantly private firms, thus mitigating the crowding out that has undermined the expansion of the more productive private sector in recent years.

The conclusion that China's recent growth is below potential is contrary to the widely quoted view of Lant Pritchett and Larry Summers (2014), who argue that periods of super rapid economic growth are invariably followed by reversion to the mean. This approach led them to predict that China's growth between 2003 and 2033 might fall to as low as 2 per cent per capita. Their prediction, of course, could turn out to be correct. But, with appropriate further reforms, I believe China's growth would be somewhat more rapid than in recent years.

It is too early to make a definitive judgement on whether an enhanced role of the state and diminished role of the market in resource allocation can be the basis for successful, sustainable development in China. But the early evidence is not promising. China's most ambitious and longest-lived industrial policy to date, the program of investment and mergers orchestrated by SASAC, has certainly fallen short. And the reduction in the role of the market under President Xi has slowed China's economic growth.

\section{References}

Communist Party of China (CPC) Central Committee (2013), Decision on major issues concerning comprehensively deepening reforms, China Daily, 16 November. Available from: www.china.org.cn/china/third_plenary_session/ 2013-11/16/content_30620736.htm.

Garnaut, R., Song, S., Tenev, S. and Yao, Y. (2005), China's Ownership Transformation: Process, outcomes, prospects, Washington, DC: International Finance Corporation and International Bank for Reconstruction and Development.

Kennedy, S. and Johnson, C. K. (2016), Perfecting China, Inc.: The 13th five-year plan, Washington, DC: Center for Strategic and International Studies.

Lardy, N. R. (1998), China's Unfinished Economic Revolution, Washington, DC: Brookings Institution Press.

Lardy, N. R. (2014), Markets over Mao: The rise of private business in China, Washington, DC: Peterson Institute for International Economics. 
Lardy, N. R. (2016), The changing role of the private sector in China, in Structural Change in China: Implications for Australia and the world, Sydney: Reserve Bank of Australia.

Ma, G. (2007), Who pays China's bank restructuring bill?, Asian Economic Papers 6(1): 31. doi.org/10.1162/asep.2007.6.1.46.

Mano, R. C. and Stokoe P. (2017), Reassessing the Perimeter of Government Accounts in China, IMF Working Paper WP/17/272, November, Washington, DC: International Monetary Fund.

McGregor, J. (2012), No Ancient Wisdom, No Followers: The challenges of Chinese authoritarian capitalism, Westport, CT: Prospecta Press.

McGregor, R. (2010), The Party: The secret world of China's communist rulers, New York: Harper Collins.

Ministry of Finance (MOF) (2015), Finance Yearbook of China 2015, Beijing: China Financial Magazine Publishing House.

Ministry of Finance (MOF) (2016), Finance Yearbook of China 2016, Beijing: China Financial Magazine Publishing House.

Ministry of Finance (MOF) (2017), Finance Yearbook of China 2017, Beijing: China Financial Magazine Publishing House.

National Bureau of Statistics (NBS) (2007), China Statistical Yearbook 2007, Beijing: China Statistics Press.

National Bureau of Statistics (NBS) (2016a), China Statistical Abstract 2016, Beijing: China Statistics Press.

National Bureau of Statistics (NBS) (2016b), China Statistical Yearbook 2016, Beijing: China Statistics Press.

National Bureau of Statistics of China (NBS) (2017), China Statistical Yearbook 2017, Beijing: China Statistics Press.

National Bureau of Statistics (NBS) and Ministry of Human Resources and Social Security (2018), China Labour Statistical Yearbook 2017, Beijing: China Statistics Press.

National People's Congress (NPC) Standing Committee (1995), Commercial Bank Law of the People's Republic of China, 10 May, in Almanac of China's Finance and Banking, Beijing: Financial Publishing House.

Naughton, B. (2016), Restructuring and reform, in Structural Change in China: Implications for Australia and the world, Sydney: Reserve Bank of Australia. 
Prichett, L. and Summers, L. (2014), Asiaphoria meets regression to the mean, NBER Working Paper 20573, October, Cambridge, MA: National Bureau of Economic Research. Available from: www.nber.org/papers/w20573. doi.org/ $10.3386 / \mathrm{w} 20573$.

State-owned Assets Supervision and Administration Commission (SASAC) (2006), The state economy must guarantee absolute controlling power over seven sectors, China Daily, 19 December.

United States Department of Commerce (2017), A-570-053 Investigation, Public Document E\&C VI: MJH/TB, Washington, DC: US Department of Commerce. Available from: enforcement.trade.gov/download/prc-nme-status/ prc-nme-review-final-103017.pdf. 
This text is taken from China's 40 Years of Reform and Development: 1978-2018, edited by Ross Garnaut, Ligang Song and Cai Fang, published 2018 by ANU Press, The Australian National University, Canberra, Australia.

doi.org/10.22459/CYRD.07.2018.18 